\title{
PEMODELAN TSUNAMI SEBAGAI BAHAN MITIGASI BENCANA STUDI KASUS SUMENEP DAN KEPULAUANNYA
}

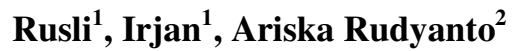

Abstrak: Indonesia adalah tempat pertemuan tiga lempeng yaitu lempeng Eurasia, IndoAustralia dan Pasifik. Karena Indonesia dua pertiganya adalah lautan, maka gempabumi berpotensi tsunami sangat besar di Indonesia. Menurut data WinITDB dan NOAA Sumenep dan kepulauannya pernah terjadi tsunami serta didukung konsep tektonik Sumenep dan Bali-Nusa Tenggara dimana banyak patahan-patahan aktif yang juga dalam sejarahnya pernah terjadi gempabumi pembangkit tsunami. Penelitian ini dilakukan di BMKG Tretes, dengan menggunakan data tsunami yaitu WinITDB dan NOAA sedangkan untuk data seismisitasnya menggunakan data USGS dan Global CMT . Kemudian data itu diolah menggunakan software TUNAMI dan WinITDB. Outputnya berupa sebaran gelombang tsunami dari sumber ke semua target area, travel-timenya dan run-up yang terjadi di target area.
\end{abstract}

Kata Kunci : Tsunami, TUNAMI, Sumenep.

\section{PENDAHULUAN}

Indonesia adalah merupakan tempat pertemuan tiga lempeng yaitu lempeng Aurasia, lempeng Australia dan lempeng Pasifik. Dari aktifitas lempeng-lempeng tersebut menjadikan Indonesia rawan akan gempabumi. Karena Indonesia juga merupakan Negara kepualauan yang dua pertiga wilayahnya adalah laut, maka terjadinya tsunami akibat gempa bumi berpotensi besar di Indonesia.

Berdasarkan informasi yang didapat dari NOAA, Win ITDB (Window Integrated Tsunami Data Base) USGS dan Global CMT Sumenep dan kepulauannya merupakan wilayah yang memiliki sejarah gempabumi yang membangkitkan tsunami. Bardasarkan hasil survei Badan Koordinasi Survey dan Pemetaan Nasional (Bakosurtanal) menunjukkan, bahwa garis pantai semua pulau di kepulauan Indonesia adalah rawan tsunami, tetapi dengan tingkat kerawanan yang berbeda-beda yaitu minimum, sedang dan tinggi. Hal ini juga didukung dengan konsep umum geologi tektonik Sumenep dan kepulauannya, daerah utara pulau Bali, Jawa Timur, Nusa Tenggara sampai ke pulau Flores yang dalam sejarahnya pernah terjadi tsunami.

Selain itu pertumbuhan jumlah penduduk yang kian meningkat mengakibatkan kebutuhan akan ruang semakin terbatas sehingga pemilihan lokasi hunian juga tidak lagi mempertimbangkan risiko bencana yang mungkin terjadi. Meningkatnya

\footnotetext{
${ }^{1}$ Fisika UIN Maulana Malik Ibrahim Malang

${ }^{2}$ BMKG Tretes
} 
konsentrasi dan aktivitas penduduk di sekitar pesisir merupakan bukti bahwa tingkat kerawanan bencana tidak lagi menjadi hal utama yang perlu dipertimbangkan. Kasus ini juga yang terjadi di Sumenep dan kepulauannya, rumah-rumah para nelayan, saranasarana umum seperti sekolah, pasar banyak yang berdekatan dengan pantai, sehingga apabila terjadi tsunami akan menyebabkan banyak korban, baaik nyawa maupun harta benda.

Dari bekal informasi ini pula, penulis sangat tertarik untuk melakukan studi pemodelan tsunami guna mengetahui penyebaran gelombang tsunami dari sumber terhadap Sumenep dan kepulauannya, waktu yang diperlukan gelombang tsunami (travel time) dari sumber ke Sumenep dan kepulauannya, dan ketinggian tsunami (runup) di Sumenep dan kepulauannya serta guna memprediksi zona rawan tsunami untuk wilayah Sumenep dan kepulauannya.

Penelitian ini bermanfaat antara lain; Sebagai bahan acuan bagi Pemda Sumenep untuk relokasi dan pengembangan pembangunan wilayah pantai. Sebagai bahan informasi tambahan bagi masyarakat dan Pemda Sumenep untuk melakukan mitigasi bencana di wilayah Sumenep dan kepulauannya serta sebagai bahan referensi bagi mahasiswa dan semua pihak yang membutuhkan kajian tentang tsunami untuk wilayah Sumenep dan kepulauannya.

\section{KAJIAN TEORI}

\section{Tsunami}

Kata "tsunami" (diucapkan "su-na-mi) adalah kata dalam bahasa Jepang yang ditulis dalam dua karakter yaitu tsu yang artinya pelabuhan dan nami yang artinya gelombang. Keduanya berarti “ gelomabang besar di pelabuhan”. Sehingga dalam istilah yang paling sederhana, tsunami adalah serangkaian gelombang laut yang umumnya paling sering diakibatkan oleh gerakan-gerakan dahsyat di dasar laut. Dalam beberapa hal, tsunami menyerupai riak-riak air yang melebar dari tempat dilemparkannya sebuah batu ke dalam air, namun tsunami dapat terjadi dalam skala yang luar biasa besarnya (Prasetya, 2006).

Tsunami disebabkan terutama oleh gempa bumi di dasar laut. Selain itu juga bisa disebabkan tanah longsor yang terjadi di laut, letusan gunung api dasar laut, atau akibat jatuhnya meteor tapi jarang terjadi atau oleh perbuatan manusia itu sendiri seperti percobaan bom nuklir di laut (Dudley dan Lee, 2006).

Terjadinya tsunami yang dipicu gempa bumi tektonik menurut Triton $(2009 ; 150)$, ada beberapa faktor yang menjadi penentunya yaitu:

1. Episenter (Pusat Gempa) terjadi di dasar laut,

2. Kedalaman Fokus (Sumber Gempa) adalah dangkal, pada umumnya kurang dari $50 \mathrm{~km}$,

3. Magnitudo gempa besar, pada umumnya di atas $\mathrm{M}=6,5 \mathrm{SR}$,

4. Gerak pemicu gempa adalah vertikal (dip-slip), bukan horisontal (strike-slip),

5. Topografi, kelandaian dan bentuk dari pantai yang sesuai, dan 
6. Adanya kandungan energi tsunami yang cocok bagi terbentuknya gelombang yang mampu membenahi dirinya sendiri, sehingga berwujud sebagai satu gelombang soliter (soliton), bukan gelombang acak (galau).

Tsunami adalah gelombang panjang yang merambat dari tempat terjadinya di lautan terbuka dengan kecepatan rambat sangat tinggi ke segala penjuru menuju perairan dangkal menjelang garis pantai. Kecepatan rambat gelombang tsunami dapat dihitung menggunakan rumus:

$v=\sqrt{g h}$

dimana $v$ adalah kecepatan rambat gelombang tsunami, $g$ adalah percepatan gravitasi dan $\mathrm{h}$ adalah kedalaman lautan. Sehingga panjang gelombang tsunami dapat ditentukan dengan menggunakan persamaan:

$\lambda=v T$

dimana $\lambda$ adalah panjang gelombang (jarak antara 2 puncak), $v$ adalah kecepatan rambat gelombang dan $T$ adalah periode gelombang (waktu yang ditempuh di antara 2 puncak) yang nilainya tetap untuk suatu tsunami tertentu (Nelson, 2009)

Energi yang dikandung gelombang tsunami praktis tidak mengalami redaman, sehingga mampu merambat puluhan ribu kilometer di lautan terbuka, di mana seluruh massa air bergerak bersama dari permukaan sampai dekat ke dasar laut dan tidak terpengaruh oleh gelombang-gelombang lokal apapun, seperti yang disebabkan oleh angin atau pasang surut, yang dijumpai dalam perjalanannya. Energi tersebut adalah sebanding dengan kuadrat tinggi (amplitudo) gelombang dan panjang gelombang. Tinggi gelombang di lautan terbuka adalah relatif kecil, pada umumnya kurang dari 1 $\mathrm{m}$, sehingga tidak dapat dirasakan oleh kapal yang sedang berlayar di atasnya atau terdeteksi oleh pengamatan melalui satelit. Dengan dicapainya lautan dangkal menjelang garis pantai, kecepatan rambat gelombang melemah oleh tahanan dari dasar laut, sehingga panjang gelombang juga berkurang. Akibat berkurangnya kecepatan rambat dan panjang gelombang, maka dari hukum kekekalan massa dan energi, tinggi gelombang akan mencuat ke atas. Tinggi air yang mencuat ini disebut run-up dan kalau terjadi pembesaran (amplifikasi) oleh geometri teluk atau muara sungai, maka dapat terjadi dinding air yang hampir vertikal yang disebut water bore. Air yang mencuat tinggi inilah yang menenggelamkan daerah pantai yang dilanda tsunami.

\section{Kondisi Tektonik Madura Sumenep}

Untuk kondisi tektonik Madura Sumenep tidak terlepas dari tektonik di selatan pulau Jawa - Bali yaitu lempeng Indo-Australia yang bergerak relatif ke utara menumbuk lempeng Eurasia, proses subduksi ini menimbulkan deformasi dan membentuk palung Jawa (Java Trench) yang secara umum mempengaruhi aktifitas gempa di Jawa Timur termasuk Madura Sumenep. Pergerakan ini menimbulkan pergeseran lempeng tektonik pada batas lempeng yang berada di selatan pulau Jawa yang mengakibatkan terjadinya medan stress atau tekanan-tekanan mulai dari batas lempeng sampai beberapa ratusan kilometer ke utara hingga ke selat Madura (Sumenep) 
dan membentuk sesar-sesar atau patahan-patahan regional maupun lokal dimana terjadi pelepasan energi atau stress tersebut berupa gempa tektonik yang berpotensi tsunami.

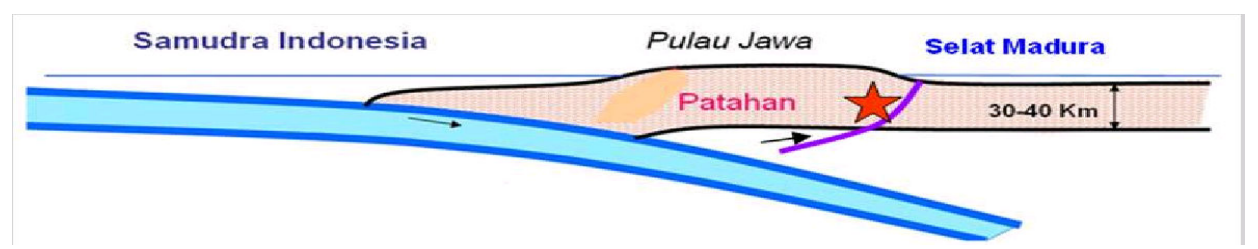

Gambar 1. Subduksi Lempeng Indo-Australia terhadap Eurasia di pulau Jawa (Sumber BMKG)

Adapun patahan-patahan yang dimaksud, di sebelah utara ada patahan Madura yang memanjang ke tenggara samapai ke kepulauan Kangean dan di selatannya juga ada patahan aktif yang dalam sejarahnya pernah terjadi gempabumi yang berpotensi tsunami. Selain itu juga punggung Kangean trend yang berada pada pinggiran tenggara di paparan Sunda, serta patahan normal Sepanjang yang arahnya baratlaut-tenggara yang juga dalam sejarahnya pernah terjadi gempa yang membangkitkan tsunami serta banyak lagi patahan-patahan lain yang ada di pulau Madura Sumenep dan kepulauannya. Bisa dilihat pada gambar 2.

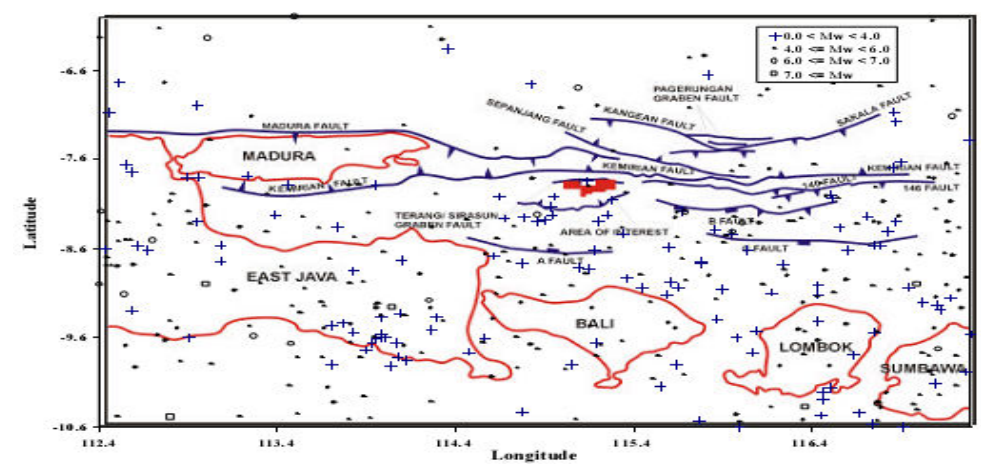

Gambar 2. Patahan-patahan Madura Sumenep dan Kepulauannya (Wayan dkk).

Disamping itu, terdapat beberapa aktifitas tektonik lain yang dapat mengakibatkan Gempabumi di wilayah Sumenep dan kepulauannya. Salah satunya adanya Backarc Thrusting yang merupakan kepanjangan Flores Thrust yang dalam sejarahnya juga pernah terjadi gempabumi yang berpotensi tsunami baik di utaranya Flores (Flores Thrust) maupun di utaranya Bali (Backarc Thrusting)

Flores Thrust yang berarah barat-timur terletak di sebelah utara Pulau Flores, sedangkan di sebelah utara Flores Thrust, kerak samudra Laut Banda Selatan menyusup ke bawah island arc Nusa Tenggara dalam pola foredeep yang perambatannya sampai ke selatannya Sumenep dan apabila gempa berpotensi tsunami maka tsunami tersebut akan merambat ke Sumenep dan kepulauannya. Selain itu lokasi kedalaman pusat gempa dan jaraknya cukup jauh dari batas konvergensi lempeng Samudera Hindia dengan Eurasia (data BMG menyebutkan kedalaman 10 km, sedangkan USGS $35 \mathrm{~km}$ ). 
Ini tetap merupakan overriding plate-earthquake; tetapi kompresif dari konvergensi lempeng terjadi jauh ke selatan (Awang H.S, diskusi IAGI-net, 2007).

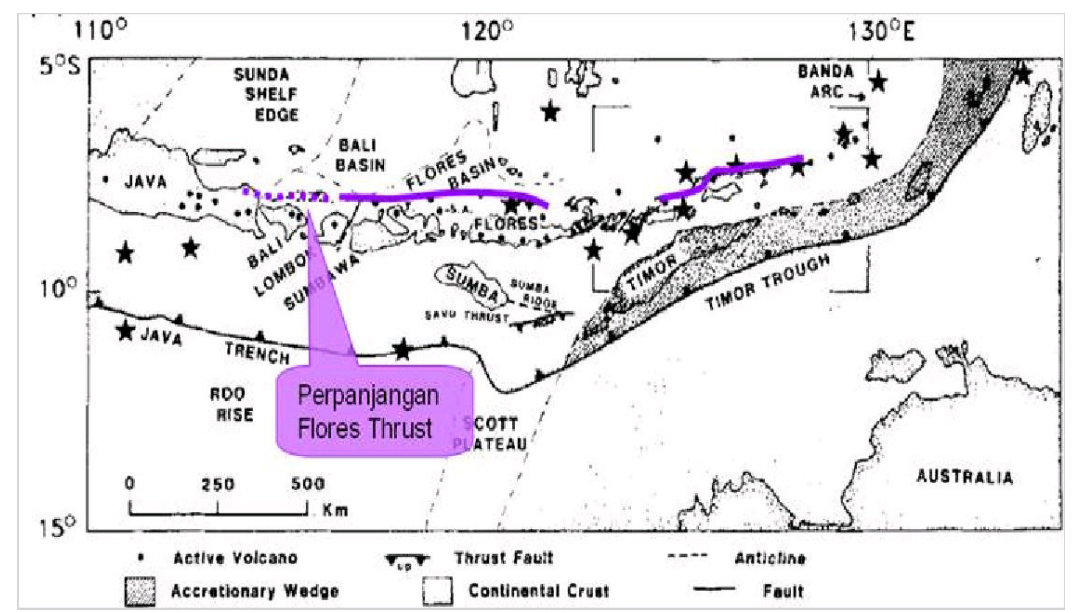

Gambar 3. Flores Thrust dan perpanjangannya. (Sumber BMG)

Hasil pemantauan Badan meteorologi dan Geofisika (BMG) pada wilayah $112^{0}$ $118^{0}$ BT dan $6^{0}-12^{0}$ LS di dalamnya termasuk wilayah Sumenep dan kepulauannya, enam tahun terakhir setelah dipasang jaringan seismograf Bali dan sekitarnya yang dikenal dengan jaringan seismograf regional III, menunjukkan jumlah yang cukup besar sekitar 5186 gempa dengan skala kurang dari 5 SR dan 848 gempa dengan skala lebih dari 5 SR. Gamabar 2.13. dan 2.14. memperlihatkan sebaran gempabumi pada daerah Bali dan Jawa Timur termasuk didalamnya kawasan Sumenep dan kepulauannya dan sensor jaringan seismograf regional III yang terdiri dari 8 seismometer telemetri perioda pendek yang di Bali (6 sensor), Lombok (1 sensor) dan Jawa Timur (1 sensor) serta 2 stasiun Geofisika yakni di Denpasar (DNP) dan Kahang-Kahang.

\section{Persamaan Shallow Water}

Dalam bentuk 3D dari gelombang shallow-water, persamaannya dapat dituliskan seperti persamaan (3) dimana dalam persamaan itu dimasukkan faktor pergeseran lantai samudera dan gaya coriolis.

$$
\begin{aligned}
& \frac{\partial U}{\partial t}+U \frac{\partial U}{\partial x}+V \frac{\partial U}{\partial y}=-f V-g \frac{\partial h}{\partial x}-C_{f} \frac{U \sqrt{U^{2}+V^{2}}}{d+h} \\
& \frac{\partial U}{\partial t}+U \frac{\partial U}{\partial x}+V \frac{\partial U}{\partial y}=f V-g \frac{\partial h}{\partial y}-C_{f} \frac{V \sqrt{U^{2}+V^{2}}}{d+h}
\end{aligned}
$$

Dan persamaan kontinuitasnya adalah sebagai berikut;

$$
\frac{\partial h}{\partial t}+\frac{\partial}{\partial x}[U(h+d)]+\frac{\partial}{\partial y}[V(h+d)]=0
$$

Dimana sistem koordinat $x=$ East and $y=$ South, $f$ adalah parameter Coriolis, $C_{f}$ adalah koefesien fraksi tidak berdimensi, $U$ dan $V$ adalah kecepatan rata-rata dalam arah 
$x$ dan $y$. Kecepatan rata-rata dari bawah ke permukaan dituliskan pada persamaan (5) dimana $Q_{x}$ dan $Q_{y}$ adalah laju alir dalam arah $x$ dan $y$.

$$
\begin{aligned}
& U=\frac{1}{(h+d)} \int_{-d}^{h} u d z=\frac{Q_{x}}{(h+d)} \\
& V=\frac{1}{(h+d)} \int_{-d}^{h} v d z=\frac{Q_{y}}{(h+d)}
\end{aligned}
$$

\section{Perhitungan Numerik}

Pemodelan penyebaran gelombang tsunami terbagi menjadi dua yaitu near-field dan far-field. Sumber tsunami jauh (far-field) dapat diatur dengan menggunakan sistem koordinat bola, dikarenakan medium yang dilalui menyerupai bentuk bumi dan sumber tsunami dekat (near-field) menggunakan system koordinat kartesian, dikarenakan medium yang digunakan relitive datar.

Penelitian ini menggunakan sumber dekat (near-field) sebagai numerical computation, yang mana turunan dari persamaan diatas sudah terintegrasi di dalam software TUNAMI.N2. Untuk memahami kerja software ini, dapat dijelaskan sebagai berikut;

Pengaturan persamaan didalam koordinat kartesian, didasarkan pada asumsi dari teori shallow-water yang menyatakan bahwa percepatan vertikal partikel air adalah diabaikan dibandingkan dengan percepatan gravitasi kecuali untuk persebaran tsunami di Samudera. Dilain pihak percepatan vertikal partikel air memiliki dampak pada sebaran tekanan hidrostatik. Persamaan nonlinier dari pergerakan (kekekalan momentum) dan persamaan kontinuitas (kekekalan massa) dalam 2D koordinat cartesian dapat diekspresikan pada persamaan berikut (Imamura 1995, dalam Zaty Aktar, 2006).

$$
\begin{aligned}
& \frac{\partial \eta}{\partial t}+\frac{\partial M}{\partial x}+\frac{\partial N}{\partial y}=0 \\
& \frac{\partial M}{\partial t}+\frac{\partial}{\partial x}\left(\frac{M^{2}}{D}\right)+\frac{\partial}{\partial y}\left(\frac{M N}{D}\right)+g D \frac{\partial \eta}{\partial x}+\frac{g n^{2}}{D^{7 / 3}} M \sqrt{M^{2}+N^{2}}=0 \\
& \frac{\partial N}{\partial t}+\frac{\partial}{\partial x}\left(\frac{M N}{D}\right)+\frac{\partial}{\partial y}\left(\frac{N^{2}}{D}\right)+g D \frac{\partial \eta}{\partial y}+\frac{g n^{2}}{D^{7 / 3}} N \sqrt{M^{2}+N^{2}}=0
\end{aligned}
$$

Dimana $x$ dan $y$ adalah sumbu horisontal dan $z$ adalah sumbu vertical, $\mathrm{t}$ waktu, $\eta$ perpindahan vertikal dari permukaan air, $g$ percepatan gravitasi, $D$ total kedalaman air yang diberikan oleh $h(x, y)+\eta, M$ dan $N$ dalah komponen dari pelepasan fluks dalam arah sumbu -x dan sumbu -y yang mana dapat dituliskan sebagai

$$
\begin{aligned}
& M=\int_{-h}^{\eta} u d z=u(h+\eta)=u D \\
& N=\int_{-h}^{\eta} v d z=v(h+\eta)=v D
\end{aligned}
$$


Persamaan (6) dapat disederhanakan dengan mempertimbangkan gerakan pada lantai samudera (bottom friction) dan faktor nonliner ditiadakan. Sehingga penyelesaian persamaan (6) dalam koordinat kartesian adalah sebagai berikut:

$$
\begin{aligned}
& \eta_{i j}^{k+1}=\eta_{i j}^{k}+\frac{\Delta t}{\Delta x}\left(M_{i+1 / 2, j}^{k+1 / 2}-M_{i-1 / 2, j}^{k+1 / 2}\right)+\frac{\Delta t}{\Delta y}\left(N_{i, j+1 / 2}^{k+1 / 2}-M_{i, j-1 / 2}^{k+1 / 2}\right) \\
& M_{i+1 / 2, j}^{k+1 / 2}=M_{i+1 / 2, j}^{k-1 / 2}-g \frac{\left(D_{i, j+1}^{k}+D_{i, j}^{k}\right)}{2} \frac{\Delta t}{\Delta x}\left(\eta_{i, j+1}^{k}-\eta_{i, j}^{k}\right) \\
& N_{i, j+1 / 2}^{k+1 / 2}=N_{i, j+1 / 2}^{k-1 / 2}-g \frac{\left(D_{i, j+1}^{k}+D_{i, j}^{k}\right)}{2} \frac{\Delta t}{\Delta y}\left(\eta_{i, j+1}^{k}-\eta_{i, j}^{k}\right)
\end{aligned}
$$

Stabilitas kwantitatif dalam pemodelan tsunami adalah Current number (C.F.L. Coundition). Dimana stabilitas ini digunakan untuk menghindari perhitungan yang tidak diinginkan, sehingga standart yang diberikan adalah waktu temporal kisi harus lebih rendah dari pada kondisi stabilnya.

$\Delta t \leq \frac{\Delta x}{\sqrt{2 g h_{\max }}}$

Untuk kondisi awal kode pemodelan tsunami digunakan apabila tidak ada gelombang udara dan air pasang. Sehingga tingkat air dari pasang surut air dapat diasumsikan konstan selama tsunami terjadi. Hal ini, mengindikasikan bahwa tidak ada gerakan yang melebihi (n-1). sebagaimana dalam persamaan (10) (Imamura, dkk., 2006);

$\eta_{i, j}^{n-1}, M_{i+1 / 2, j}^{n-1 / 2}, N_{i, j+1 / 2}^{n-1 / 2}$

Kondisi terbuka pada skema staggered leap-frog adalah menggunakan pendekatan sederhana untuk memperoleh nilai batas dari $\eta$ dengan asumsi bahwa hubungan tinggi gelombang $h$ dan kecepatan $u$ pada kedalaman konstan adalah;

$u= \pm \sqrt{\frac{g}{h}} \cdot \eta$

Skema staggered leap-frog merupakan pemecahan dalam pengaturan persamaan numerik dalam koordinat bola dan kartesian pada model numerik tsunami. Skema ini adalah sistem kisi-kisi dalam daerah straggeringly (goncangan). Dimana $M$ atau $N$ adalah kisi-kisi sedangakan $\eta$ dan $h$ adalah bagian dari pusat kisi (gambar 2.12). Keunggulan dari skema staggered leap-frog adalah kesederhanaannya dalam memecahkan persamaan near-field dan far-field dengan kesalahan yang rendah dan mudah dalam menentukan batas kondisi, sangat stabil dan ada-tidaknya kesalahan hamburan. 


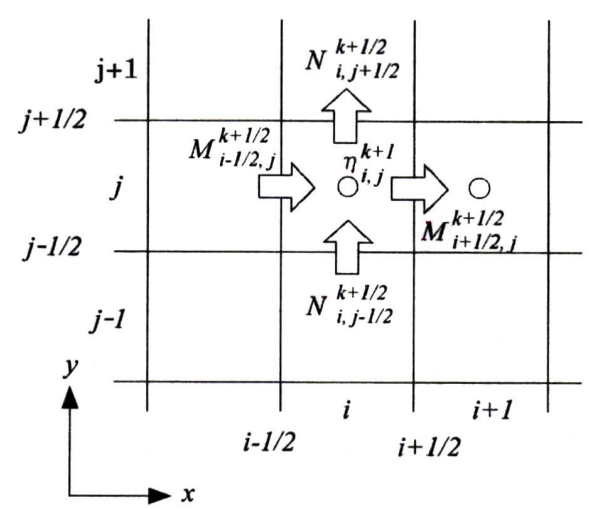

Gambar 4. Ruang geometri dari Skema Staggered Leap-Frog (Khosimura, 2008)

\section{Deformasi Patahan dan Parameter Patahan}

Dalam pemodelan tsunami perlu adanya penetuan parameter patahannya. Parameter-parameter sesar seperti panjang (L) dan lebar sesar (W), energi dan magnitude, kedalaman pusat gempa (H), slip (D) dan mekanisme fokus (strike $(\phi)$, dip $(\delta)$, dan sudut slip $(\lambda)$ ) adalah parameter-parameter yang utama dari sumber gempa (Gambar 5), yang berfungsi untuk pembentukan awal tsunami sebelum tsunami itu menyebar.

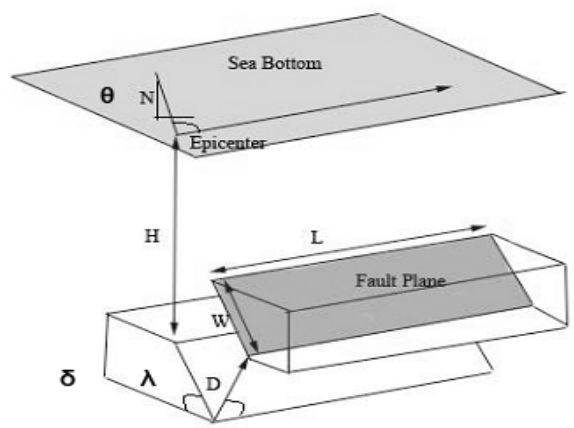

Gambar 5. Parameter-parameter sesar (Sumber JMA, 2007)

\section{Target Area Terimbas Tsunami dan Letak Sumber Tsunami}

Untuk daerah penelitian adalah wilayah Sumenep dan kepulauannya dengan koordinat $113.5^{0}-116^{0} \mathrm{BT}$ dan $5^{0}-7^{0} \mathrm{LS}$ yang di dalamnya ada 20 tempat yang dijadikan objek datangnya tsunami ke daerah itu. Titik-titik tersebut adalah tempat yang dipandang sebagai tempat yang vital apabila tsunami datang misalnya penduduknya padat, tempat wisata, pertambangan, pasar, dan lain sebagainya. Tempat yang dimaksud adalah, Kalianget, Tanjung, Tanjung Lopak, Badur, Pragaan, Romben, Pantai Lombang, Pantai Slopeng, Ambunten, Pasongsongan, Pantai Ponjuk Garam, Puteran, Pulau Gili Raja, Pulau Gili Genting, Pulau Spudi, Pulau Raas, Pulau Kangean, Pulau Spanjang, Pulau Pagerrungan, Pulau Masalembu.

Sedangkan untuk sumber tsunami mengambil empat sumber. Pertama sumbernya berada di utara pulau Bali. Kedua berada di selatan Sumenep berdekatan 
dengan pulau Gili Genting, dan Gili Raja. Sumber yang ketiga berada di kepulauan Sumenep dekat dengan pulau Pagerrungan dan Kangean dan yang terakhir di selatan pulau Nusa Tenggara.

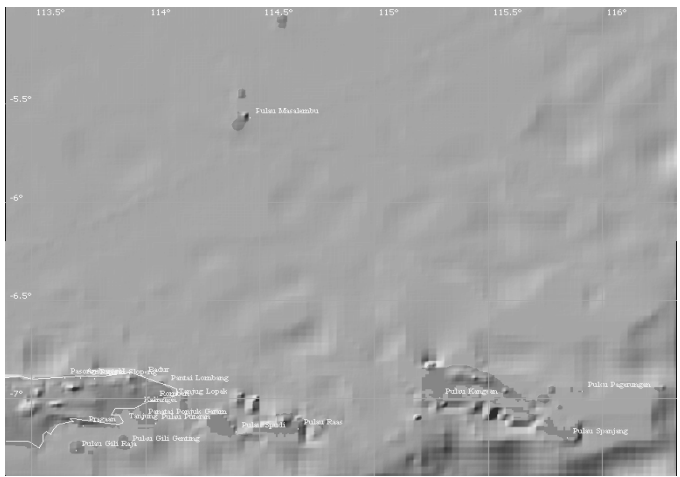

(a)

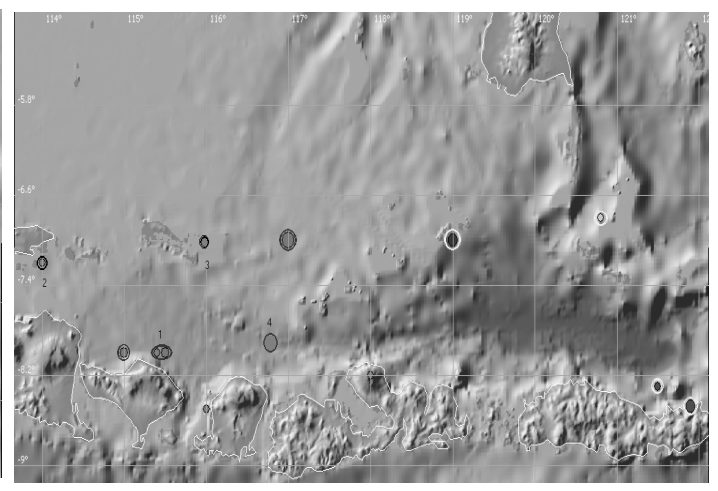

(b)

Gambar 6. (a) 20 Target Area Terimbas tsunami (b) Letak 4 Sumber Tsunami

\section{HASIL DAN PEMBAHASAN}

Pada penelitian ini terdapat 4 kasus, casel case 2 case 3 dan case 4 . Setiap case terdapat dua pemodelan pertama menggunakan data historis yang kedua menggunakan pendekatan data historis. Letak dan mekanisme fokusnya sama perbedaannya pada magnitudenya.

\section{Case1}

Pada case 1 merupakan lokasi gempabumi membangkitkan tsunami yang berada di utara pulau Bali pada tahun 1815 dengan koordinat $115.4^{\circ} \mathrm{LS}$ dan $8^{\circ} \mathrm{BT}$, magnitude 7 SR dan kedalaman $8.62 \mathrm{~km}$.

Pada menit ke-0 tsunami berada di pulau Bali baru setelah menit ke-20 tsunami megimbas pulau Spanjang, dan pulau-pulau kecil yang di selatan Kangean. Pada menit ke-60 sebaran gelombang tsunami diprediksi sudah mengimbas pulau Pagerrungan, Kangean, Raas dan Spudi, tetapi belum sampai ke pulau Gili Genting, Gili Raja dan daerah yang berada di Sumenep seperti Kalianget, pantai Lombang, Tanjung dan lain sebagainya.

Setelah 90 menit sebaran tsunami diperkirakan sudah mengimbas semua pulau yang ada di Sumenep, yaitu pulau Gili Genting, Gili Raja, Talango, Puteran dan termasuk Kalianget, Tanjung, Tanjung Lopak, Pragaan, dan Pantai Lombang tapi untuk kawasan Sumenep bagian utara seperti Pantai Slopeng, Ambunten dan Pasongsongan masih belum terimbas karena letaknya memang berada di utara dan banyak pulau-pulau yang menghadang sehingga daerah-daerah tersebut masih sulit terimbas. Pada menit ini juga gelombang gelombang tsunami saling memantul dan terperangkap pada pulaupulau tersebut sehingga gelombang tsunami mengimbas pulau-pulau tersebut lebih lama dan gelombang tsunami tersebut semakin tinggi. Hal ini biasanya disebut resonansi tsunami. Baru pada menit ke-180 gelombang tsunami mengimbas semua target area 
termasuk didlamnya pantai Slopeng, Ambunten, Pasongsongan dan pulau yang paling utara yaitu pulau Masalembu meskipu dengan intensitas dan ketinggian yang rendah.

Run-up maksimum berada di Pulau Spanjang dengan ketinggian 0,4 meter yaitu terjadi dari menit ke-15 sampai ke-20. Sedangkan tinggi maksimum kedua yaitu dengan ketinggian 0,25 meter yang terjadi pada menit ke-30 sampai ke-40 terjadi di pulau Kangean, Pagerrungan, Sepudi, Raas, Gili Genting, Gili Raja serta pulau Talango dan Puteran. Sedangkan untuk run-up maksimum ketiga yaitu dengan ketinggian 0,1 meter terjadi pada menit ke-90 untuk daerah Sumenep bagian selatan yaitu Kalianget, Tanjung, Pragaan dan Tanjung Lopak serta Masalembu. Sedangkan tempat dengan ketinggian gelombang tsunami 0 meter yaitu berada pada daerah-daerah sebelah utara Sumenep seperti Pantai Lomabang, Badur, Pantai Slopeng, Ambunten dan Pasongsongan. Karena memang letaknya membelakangi sumber tsunami dan di hadang oleh semua pulau yang ada di Sumenep dan kepulauannya.

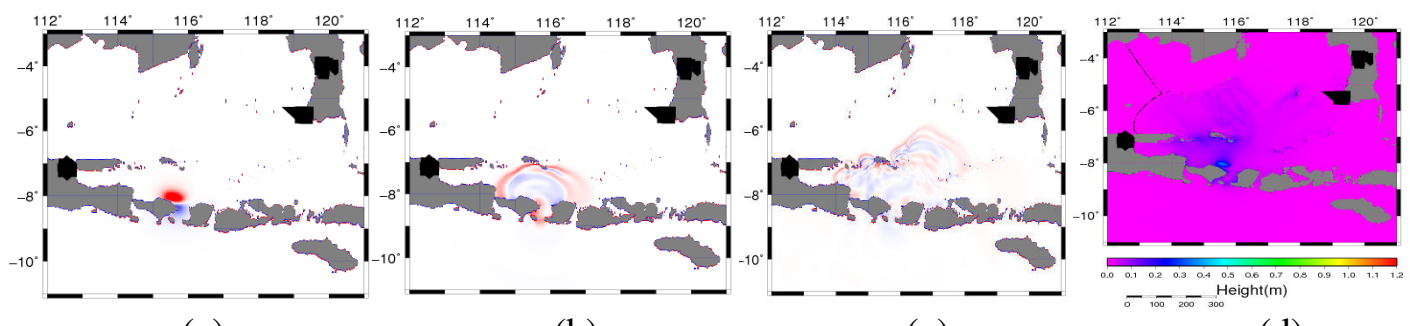

(a)

(b)

(c)

(d)

Gambar 7. (a) sebaran tsunami Pada menit ke-0 (b) menit ke-20 (c) menit ke-60 (d) Run-up maksimum.

Pemodelan selanjutnya dengan menggunakan pendekatan data historis dengan magnitude dan kedalaman yaitu 7,5 SR dan $4.03 \mathrm{~km}$. Sedangkan lokasi gempabumi pembangkit tsunami yaitu sama berada di utara pulau Bali dengan koordinat $115.4^{\circ} \mathrm{BT}$ dan $8^{\circ}$ LS.

Pada menit ke-0 gelombang tsunami masih berada di utara Bali diprediksi pada menit ini Bali sudah terimbas tsunami. Sebaran tsunami pada ke-10 awal menunjukkan gelombang tsunami telah mengimbas pulau Spanjang karena letak pilau Spanjang tegak lurus dengan sumber tsunami.

Pada menit ke-60 gelombang tsunami sudah mengimbas beberapa pulau yaitu pulau Kangean, Pagerrungan, Raas, dan Sepudi tetapi belum sampai ke daerah-daerah yang ada di Sumenep seperti Kalianget, Tanjung Lopak, Tanjung, Pantai Lombang, Slopeng, Ambunten dan Pasongsongan serta pulau Gili Raja, Gili Genting dan pulau Puteran. Pada menit ini gelombang tsunami saling memantul antar pulau-pulau tersebut sehingga durasi waktu dan ketinggian tsunami semakin meningkat. Baru pada menit ke90 sebaran tsunami menunjukkan gelombang tsunami sudah mengimbas daerah-daerah yang ada di Sumenep seperti Kalianget, Tanjung Lopak, Tanjung, Pantai Lombang serta pulau Puteran, Pulau Talango, Gili Genting, dan Gili Raja.

Sebaran tsunami pada menit ke-180, gelombang tsunami diprediksi masih mengimbas wilayah Sumenep dan kepulauannya. Semua daerah target area pada menit ini telah terimbas tsunami baik daerah yang ada di utara Sumenep seperti Slopeng, Ambunten, dan Pasongsongan bahkan sampai pulau yang terjauh yang berada di utara 
Sumenep yaitu pulau Masalembu tetapi dengan intensitas dan tinggi gelombang tsunami yang sudah tidak begitu besar. Diperkirakan juga bahwa gelombang tsunami bukan hanya mengimbas Sumenep dan kepulauannya tetapi juga mengimbas Pamekasan, Sampang, Bangkalan dan Surabaya, Probolinggo dan Situbondo.

Run-up maksimum berada di pulau Spanjang bagian selatan, pulau Kangean bagian selatan dan pulau Pagerrungan dengan ketinggian gelombang sebesar 0,65 meter yang terjadi pada menit ke 20 sampai 30. Run-up maksimum kedua berada di Pulau Raas bagian timur dan sebagian kecil pulau Sepudi pada menit ke-20 sampai ke-30 dengan ketinggian gelombang 0,5 meter. Untuk run-up maksimum ketiga berada di pulau Talango termasuk di dalamnya Pantai Ponjuk Garam, Gili Raja, Gili Genting, Kalianget, Tanjung, dan Tanjung Lopak dengan ketinggian 0,25 meter, dprediksi terjadi pada menit ke-90 sampai ke-100. Sedangkan untuk run-up minimum berada di utara Sumenep yaitu Pantai Lombang, Slopeng, Ambunten, dan Pasongsongan serta pulau Masalembu yang berada di utara Sumenep dengan ketinggian 0,15 meter.

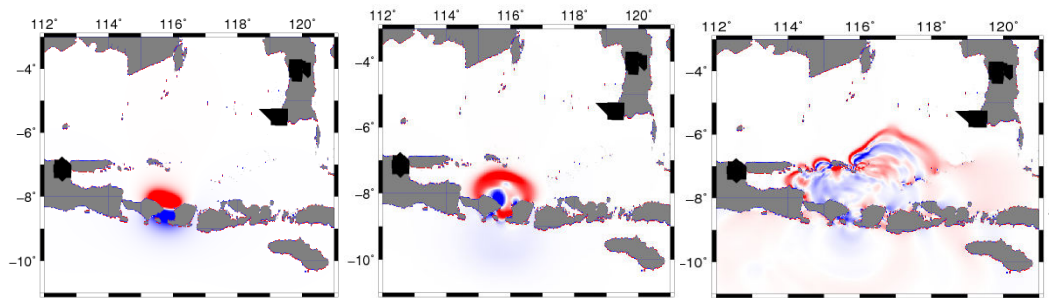

(a) (b) (c)

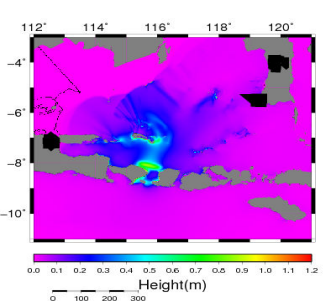

(d)

Gambar 8. (a) sebaran tsunami Pada menit ke-0 (b) menit ke-20 (c) menit ke-60 (d) Run-up maksimum.

\section{Case 2}

Pemodelan tsunami pada case 2 ini pertama dengan menggunakan data historis. Lokasi gempabumi pembangkit tsunami berada di selatan Sumenep berdekatan dengan pulau Gili Raja dan Gili Genting. Secara astronomis letak gempabumi pembangkit tsunami berada pada koordinat $114^{0} \mathrm{BT}$ dan $7.2^{0} \mathrm{LS}$ dengan magnitude $6.5 \mathrm{SR}$ dan kedalaman $30.63 \mathrm{~km}$.

Pada menit ke-0 gempa pambangkit tsunami berada di selatan Sumenep dan diprediksi gelombang tsunami telah menyapu pulau Gili Genting dan Gili Raja. Sebaran tsunami pada menit ke-10 awal sampai menit ke-60 daerah yang terimbas tsunami masih daerah di sekitar Kalianget, Gili raja, Gili Genting, pulau Sepudi, pulau Talango, pantai Ponjuk Garam, Pragaan,Tanjung, Tanjung Lopak. Setelah menit ke-60 gelombang tsunami mengimbas pulau Raas dan gelombang mulai bergerak ke barat. Karena pada menit ke-10 samapi ke-60 gelombang tsunami masih saling memantul antar pulau-pulau tersebut sehingga terperangkap dan tidak bisa menyebar secara bebas.

Sebaran tsunami pada menit ke-90, tsunami diprediksi sudah mengimbas pulau Kangean, tetapi dengan intensitas dan ketinggian yang sangat kecil mungkin hanya berupa riak-riak gelombang kecil. Pada menit ke-180 menunjukkan bahwa sebaran tsunami yang terjadi di Sumenep dan kepulauannya diprediksi sudah reda bahkan dirasa 
sudah tidak ada riak gelombang tsunami pada daerah wilayah Sumenep dan kepulauannya. Pada menit ini, tsunami diprediksi sudah masuk pada area pesisr mengingat tinggi gelombang hanya 0.35 meter.

Tinggi run-up maksimum tsunami pada pemodelan menggunakan data historis pada case 2 sangat kecil dan hanya mencakup wilayah Kalianget dan sekitarnya. Tinggi maksimum terjadi pada 0 menit sampai 10 menit awal, yaitu melanda pulau Gili Raja, Gili Genting, Talango dan Spudi dengan ketinggian 0.35 meter, karena jaraknya yang sangat dekat dan berhadapan langsung dengan sumber tsunami. Kemudian untuk wilayah Kalianget, Tanjung, Tanjung Lopak dan Pragaan ketinggian tsunami diperkirakan 0.15 meter. Meskipun dekat dengan sumber tsunami tetapi daerah tersebut terhalang oleh pulau-pulau, seperti pulau Talango, Gili Raja, Gili Genting dan Sepudi sehingga gelombang tsunami masih terhalang dan mengakibatkan energinya tambah kecil sehingga run-up pada kawasan tersebut tidak terlalu besar. Untuk daerah lain seperti pulau Masalembu, Kangean, Spanjang dan Pagerrungan serta daerah-daerah di utara Sumenep run-up tsunami 0 meter.

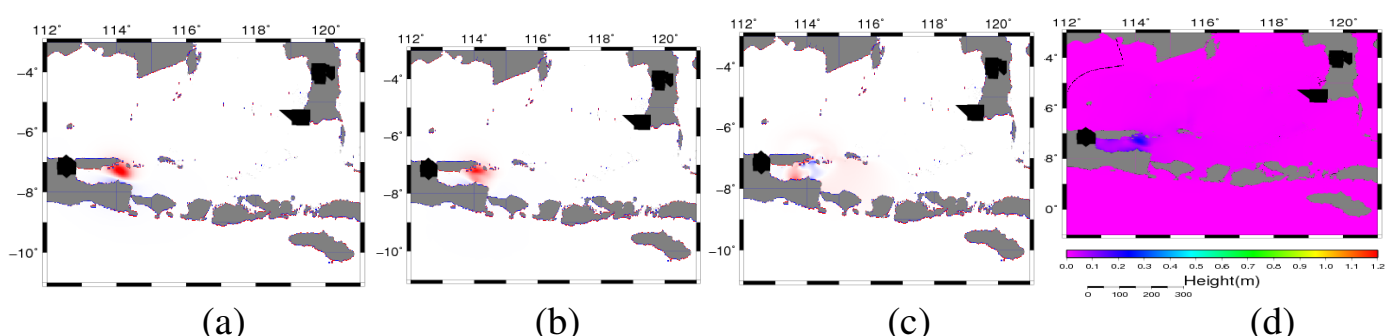

Gambar 9. (a) sebaran tsunami Pada menit ke-0 (b) menit ke-20 (c) menit ke-60 (d) Run-up maksimum

Selanjutnya pemodelan menggunakan pendekatan data historis dengan Lokasi gempabumi pembangkit tsunami sama yaitu berada di selatan Sumenep berdekatan dengan pulau Gili Genting dan Gili Raja yang secara astronomis pada koordinat $114^{0}$ BT dan $7.2^{0} \mathrm{LS}$, magnitude $7 \mathrm{SR}$ dan kedalaman $21 \mathrm{~km}$.

Pada menit ke-0 sebaran tsunami sudah menerjang Kalianget, Tanjung, Tanjung Lopak, Pragaan, pulau Talango, Gili Raja dan Gili Genting bahkan sampai ke pulau Spudi dan Raas. Gelombang tsunami pada menit ini masih menyebar di perairan ini, hal ini disebabkan gelombang tsunami tidak bisa bergerak bebas karena terperangkap dan saling memantul antar pulau-pulau yang berada di selatan Sumenep sehingga menyebabkan peningkatan ketinggian gelombang dan memperpanjang durasi waktu gelombang tsunami menerjang suatu kawasan tersebut.

Pada menit ke-60 sebaran gelombang tsunami masih terperangkap di kawasan Kalianget dan pulau-pulau yang ada di sekitarnya. Tetapi mulai menyebar ke daerah yang berada di utara Sumenep seperti pantai Lombang dan Badur tetapi belum sampai ke Pantai Slopeng, Ambunten, Pasongsongan, pulau Kangean, Spanjang dan Pagerrungan tetapi dengan intensitas dan ketinggian yang rendah. 
Gelombang tsunami baru lepas dari Kalianget dan sekitarnya setelah 90 menit berlalu. Dan sebaran pada menit ke-180 menunjukkan gelombang tsunami pada perairan Sumenep dan kepulauannya sudah mulai reda akan tetapi dekat sumber masih ada riak tetapi tikak begitu besar.

Run-up maksimum gelombang tsunami pada pemodelan menggunakan pendekatan data sejarah di case 1 adalah terletak di Tanjung, pulau Gili Genting, Gili Raja, Talango yang didalamnya ada Pantai Ponjuk Garam dan pulau Spudi bagian Barat dengan ketinggian 0,6 meter yang diprediksi terjadi pada menit ke-0 samapai menit ke90. Run-up maksimum kedua berada di daearah Kalianget, Tanjung Lopak dan pulau Sepudi dengan ketinggian 0,4 meter, diprediksi terjadi di menit ke-0 sampai ke-90. Hal ini, meskipun letak Kalianget sangat dekat dengan sumber tsunami tetapi ada pulau Talango yang menghadang tsunami sebelum tsunami mencapai Kalianget. Tinggi runup maksimum yang ketiga yaitu dengan ketinggian 0,25 meter berada pada daerah Pragaan dan pulau Raas dan sebagian kecil pulau Kangean sebelah barat. Terakhir ketinggian tsunami yang hanya kurang dari 0,05 meter berada di pulau Masalembu dan Pagerrungan serta daerah-daerah yang berada di utara Sumenep yaitu Pantai Slopeng, Ambunten dan Pasongsongan.

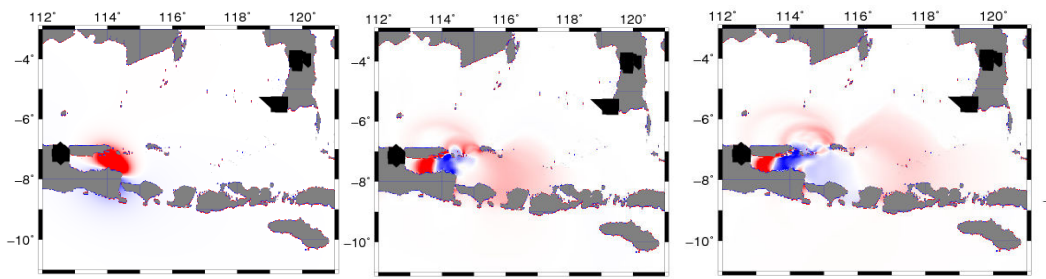

(a) (b)

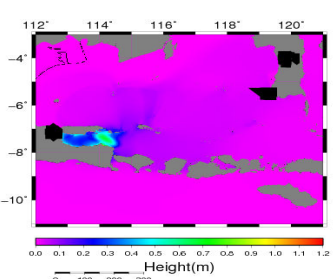

(c)

Gambar 10. (a) sebaran tsunami Pada menit ke-0 (b) menit ke-60 (c) menit ke-90 (d) Run-up maksimum.

\section{Case 3}

Pemodelan tsunami pada case 3 menggunakan data historis tsunami. Episenternya berada di kepulauan Sumenep khususnya berdekatan dengan pulau Kangean, Pagerrungan dan Spanjang yang secara astronomis berada pada koordinat $116^{0} \mathrm{BT}$ dan $7^{0} \mathrm{LS}$ dengan magnitude 6,6 SR dan kedalaman 15 kilometer.

Pada menit ke-0 menunjukkan area yang diprediksi disapu tsunami yaitu pulau Pagerrungan karena memang sumber gempa pembangkit tsunami letaknya sangat dekat dengan pulau Pagerrungan. Dan Sebaran tsunami pada menit ke-10 gelombang tsunami mengimbas pulau Spanjang. Gelombang tsunami saling memantul antara pulau Pagerrungan dan Spanjang sehingga gelombang tsunami beresonansi yang mengakibatkan durasi waktu gelombang tsunami mengimbas kedua pulau tersebut lebih lama dan ketinggiannya juga meningkat.

Sebaran pada menit ke-30 gelombang tsunami mengimbas pulau Kangean sebelah timur tetapi dengan intensitas dan ketinggian yang kecil. Pada menit ke-60 sebaran tsunami masih tetap berada di antara dua pulau tersebut tetapi dengan intensitas 
yang kecil, tetapi selain memantul gelombang tsunami juga menyebar ke barat dan utara. Setelah menit ke-90 gelombang tsunami di dua pulau tersebut reda dan diperkirakan gelombang sudah mengimbas pesisir pulau Spanjang. Sedangkan penjalaran gelomabangnya masih belum sampai ke pulau Masalembu. Pada menit ke180 sebaran gelombang tsunami diperkirakan baru sampai ke pulau Masalembu tetapi dengan intensitas dan ketinggian yang kecil sekali. Sedangkan gelombang tsunami pada menit ini pada pulau Pagerrungan dan Sepanjang sudah reda.

Run-up maksimum terjadi pada antara 0 menit samapai 30 menit dengan ketinggian 0.55 meter, berada di pulau Pagerrungan dan pulau Sepanjang. Karena kedua pulau ini sangat berdekatan dan tegak lurus dengan sumber tsunami serta gelombang tsunami dalam perambatannya saling memantul diantara dua pulau ini sehingga gelombang tsunami beresonansi menyebabkan gelombang tsunami bertambah tinggi pada dua pulau ini. Run-up maksimum kedua berada di pulau Kangean sebelah timur dan pulau Masalembu dengan ketinggian 0.1 meter. Untuk wilayah Sumenep dan pualu-pulau di sekitarnya ketinggian tsunami 0 meter karena letaknya jauh dengan sumber serta posisi kawasan tersebut menyamping dan tidak tegak lurus dengan sumber tsunami.

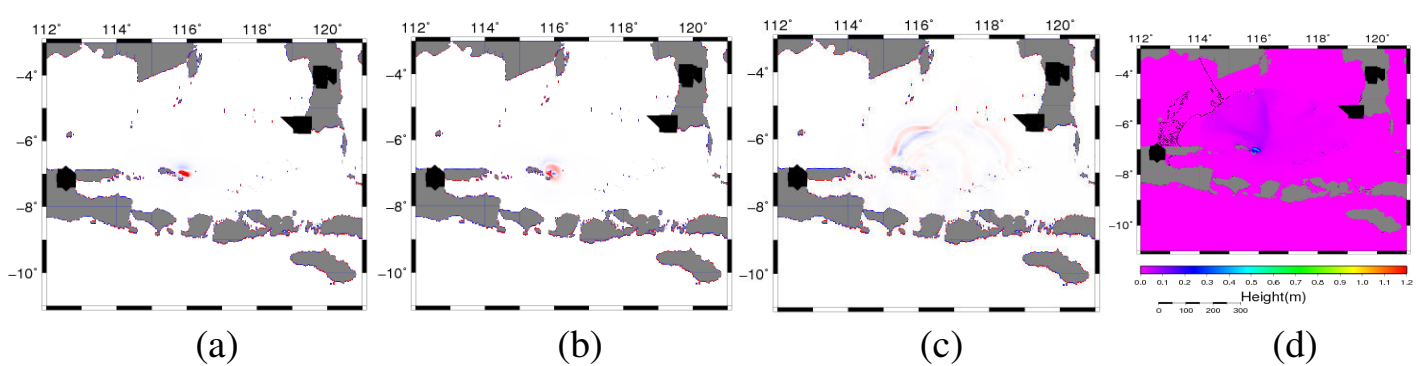

Gambar 11. (a) sebaran tsunami Pada menit ke-0 (b) menit ke-10 (c) menit ke-60 (d) Run-up maksimum.

Selanjutnya pemodelan tsunami pada case 3 menggunakan pendekatan parameter-parameter data historis. Lokasinya sama yaitu terletak di kepulauan Sumenep yaitu berdekatan dengan pulau Pagerrungan, Spanjang dan Kangean yang secara astronomis terletak di koordinat $116^{\circ} \mathrm{BT}$ dan $7^{0} \mathrm{LS}$. Perbedaanya dengan pemodelan tsunami menggunakan data hostoris adalah pada magnitude 7 SR dan kedalaman $1 \mathrm{~km}$.

Pada menit ke-0 tsunami sudah menyapu pulau Pagerrungan dan sebagian kecil kepualauan Kangean sebelah timur. Pada menit ke-10 sebaran gelombang tsunami sudah mengimbas pulau Pagerrungan. Gelombang tsunami mulai saling memantul antara dua pulau ini yaitu pulau Pagerrungan dan pulau Spanjang sehingga gelombang tsunami beresonansi yang mengakibatkan gelombang tsunami bertambah tinggi dan durasi waktu gelombang tsunami mengimbas lebih lama pada dua pulau ini samapai pada menit ke-60.

Sebaran pada menit ke-90 gelombang tsunami antara dua pulau yaitu pulau Pagerrungan dan Sepanjang sudah tidak saling memantul. Akan tetapi sebaran gelombang tsunami menjalar ke utara. Pada menit ke-120 sebaran gelombang tsunami 
muncul lagi diantara dua pulau itu lagi. Hal ini disebabkan gelombang tsunami masi terperangkap di pulau-pulau kecil dekat pulau Kangean dan menyebar lagi ke pulau Pagerrungan dan Spanjang meskipun dengan intensitas dan ketinggian yang rendah. Tetapi setelah itu gelombang ini saling memantul lagi antar dua pulau tersebut sehingga gelombang tsunami makin tinggi dan mengimbas lagi dua pulau ini. Dan Sebaran pada menit ke-180 gelombang tsunami antara dua pulau ini sudah reda kembali. Tetapi gelombang tsunami sudah mengimbas pulau Masalembu, tetapi dengan intensitas dan ketinggian yang rendah.

Run-up tsunami maksimum pada pemodelan tsunami menggunakan pendekatan data historis pada case 3 adalah sebesar 0.7 meter, berada di pulau Pagerrungan, diprediksi terjadi pada menit ke-0 samapai ke-10. Hal ini disebabkan letak pulau Pagerrungan sangat dekat dan tegak lurus dengan sumber tsunami. Run-up maksimum kedua pada pulau Spanjang dan Kangean sebelah timur dengan ketinggian sebesar 0.5 meter terjadi di menit ke-10 sampai ke-20. Run-up maksimum ketiga terletak di utara pulau Kangean dan pulau Masalembu dengan ketinggian 0.2 meter. Pulau Kangean meskipun dekat dengan sumber tsunami akan tetapi posisi pulau Kangean menyamping tidak tegak lurus dengan sumber tsunami sehingga imbasan gelombang tsunami sangat kecil terhadap pulau Kangean sebelah utara. Selain itu ketinggian tsunami 0 meter berada di kawasan Sumenep dan pulau-pulau yang ada di sekitarnya seperti pulau Gili Genting, Gili Raja dan Talango.

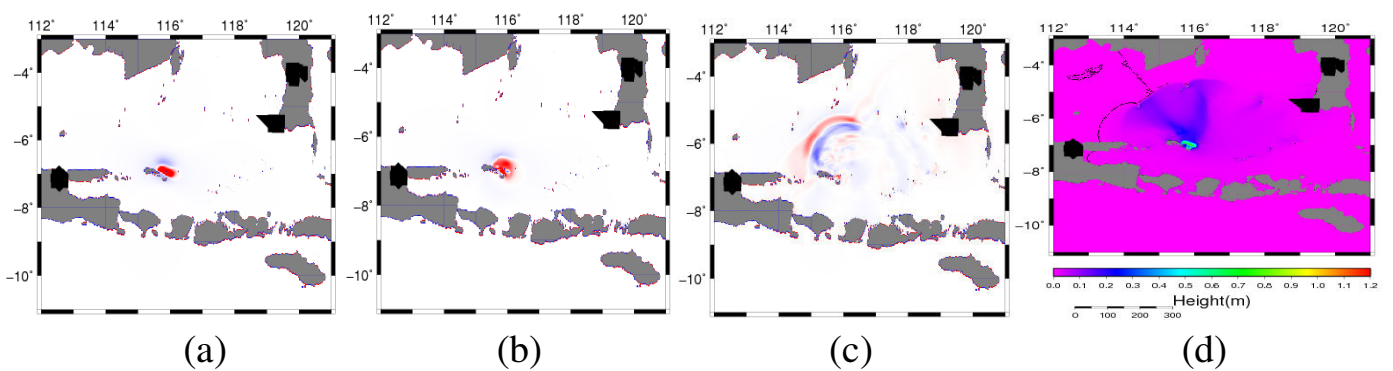

Gambar 12. (a) sebaran tsunami Pada menit ke-0 (b) menit ke-10 (c) menit ke-120 (d) Run-up maksimum.

\section{Case 4}

Pemodelan tsunami pada case 4 menggunakan data historis yang diambil dari NOAA dan WinITDB yaitu terjadi pada tahun 1818. Episenter gempa pembangkit tsunami berada di utara pulau Nusa Tenggara yang secara astronomis terletak pada $7.19^{0} \mathrm{LS}$ dan $116.82^{0} \mathrm{BT}$ dengan magnitude sebesar 8 SR dan kedalaman $2.94 \mathrm{~km}$.

Sebaran pada 0 menit tsunami menyapu pulau Nusa Tenggara. Kemudian pada menit ke-60 gelombang tsunami mengimbas pulau yang ada di Sumenep yaitu pulau Spanjang. Tetapi karena letak pulau Spanjang tidak tegak lurus tetapi sejajar dengan sumber gempa sehingga intensitas dan ketinggian tsunami tidak terlalu besar.

Sebaran pada menit ke-110 gelombang tsunami sudah mengimbas pulau Spudi setelah mengimbas pulau Kangean, Pagerrunngan dan Raas. Tetapi pada menit ini gelombang tsunami beresonansi di pulau-pulau yang ada diantara pulau Kangean dan 
Pagerrungan yang memungkinkan tinggi gelombang akan membesar dan durasi waktu gelombang tsunami mengimbas lebih lama di pulau-pulau tersebut.

Sebaran pada menit ke-180 gelombang tsunami sudah menyebar ke semua target area kecuali pulau Masalembu, dan daerah yang berada di utara Sumenep yaitu Badur, Pantai Slopeng, Ambunten dan Psongsongan. Tetapi pada menit ini gelombang tsunami masih menjalar di kepulauan Sumenep, dan saling memantul antar pulau-pulau yang ada di Sumenep, seperti yang terjadi di kepulauan Kangean dan Pagerrungan yang baru berhenti pada menit ini. Selain itu gelombang tsunami juga memantul yang mengakibatkan gelombang tsunami berinterferensi dan beresonansi di pulau-pulau yang berada di selatan Sumenep seperti pulau Spudi, Talango, Gili Genting, dan Gili Raja yang pada menit ke-180 ini masih belum berhenti sehingga menyebabkan gelombang tsunami pada pulau-pulau makin tinggi dan durasi waktunya juga lebih lama.

Run-up maksimum pada pemodelan menggunakan data historis pada case 4 ini untuk kawasan Sumenep dan kepulauannya yaitu 0,7 meter berada di pulau Talango, Gili Raja dan Gili Genting diperkirakan terjadi pada menit 150 sampai 180. Pada daerah ini meskipun jauh dengan sumber tsunami dan juga sejajar dengan sumber namun pada saat gelombang tsunami sampai pada daerah ini gelombang tsunami saling memantul antar piulau-pulau tersebut sehingga tinggi gelombang tsunami bertambah tinggi. Runup maksimum ke dua yaitu berada di pulau Spudi, Raas, Pagerrungan, Kangean bagian utara, dan sebagian pulau Spanjang bagian utara yaitu sebesar 0.5 meter terjadi pada menit ke-60 sampai ke-120. Meskipun gelombang tsunami juga memantul di pulaupulau yang ada di Kangean dan Pagerrungan tetapi pantulannya tidak sedahsyat di pulau-pulau yang berada di selatan Sumenep. Run-up maksimum yang ketiga sebesar 0.25 meter berada di pulau Kangean sebelah selatan dan barat serta pantai Lombang dan untuk tsunami yang ketinggiannya 0 meter berada di pulau Masalembu, pantai Slopeng, Ambunten dan Pasongsongan.

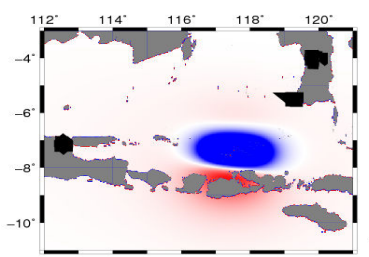

(a)

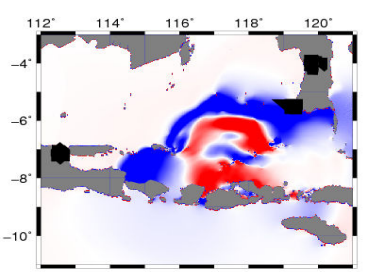

(b)

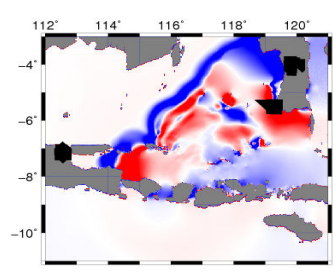

(c)

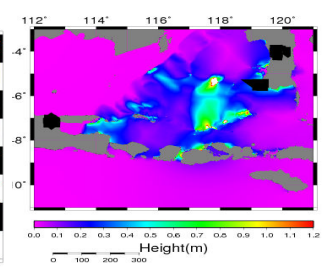

(d)

Gambar 13. (a) sebaran tsunami Pada menit ke-0 (b) menit ke-60 (c) menit ke-80 (d) Run-up maksimum.

Selanjutnya pada case 4 ini pemodelan tsunami menggunakan pendekatan parameter-parameter data historis. Lokasinya sama dengan menggunakan data historis yaitu di sebelah utara pulau Nusa Tenggara yang secara astronomis terletak pada koordinat $116.8^{0} \mathrm{BT}$ dan $7.5^{\circ} \mathrm{LS}$ tetapi magnitude dan kedalamannya berbeda yaitu 8,5 SR dan $52,93 \mathrm{~km}$.

Pada menit ke-0 menunjukkan daerah yang disapu tsunami adalah pulau Nusa Tenggara. Setelah 70 menit gelombang tsunami baru mengimbas pulau Spanjang. Pulau 
Spanjang dekat dengan sumber tsunami tetapi tidak tegak lurus dengan sumber tsunami melainkan sejajar menyamping dengan sumber tsunami sehingga gelombang tsunami masih memerlukan waktu yang cukup lama untuk mengimbas pulau tersebut.

Sebaran pada menit ke-120 gelombang tsunami telah mengimbas pulau Spudi setelah mengimbas pulau Raas, Kangean dan Pagerrungan. Akan tetapi gelombang tsunami masih saling memantul di pulau-pulau yang berada di pulau Kangean dan Pagerruangan. Sebaran tsunami pada menit ke-180 gelombang tsunami telah mengimbas semua pulau yang ada di Sumenep kecuali pulau Masalembu dan wilayah bagian utara Sumenep yaitu pantai Slopeng, Ambunten dan Pasongsongan. Selain itu pada menit ini gelombang tsunami masih belum reda dan saling memantul antar pulau sehingga ketinggiannya semakiin besar, seperti yang terjadi di pulau-pulau bagian selatan Sumenep yaitu pulau Talango, Gili Raja, Gili Genting dan Spudi. Gelombang tsunami terperangkap di pulau-pulau ini dan saling memantul menyebabkan gelombang tsunami bertambah tinggii akibatb interferensi pada pulau-pulau tersebut. Sedangkan untuk di pulau-pulau yang berada di Kangean gelombang tsunami sudah mulai reda dan mulai menjalar ke barat.

Run-up maksimum pada pemodelan tsunami menggunakan pendekatan parameter-parameter data sejarah adalah berada di pulau Gili Raja, Gili Genting, Talango yang di dalamnya ada Pantai Ponjuk Garam, Spudi dan Raas dan bagian barat pantai Kangean dengan ketinggian lebih 1,2 meter terjadi pada menit ke-90 sampai ke180. Run-up maksimum yang kedua yaitu sebesar 1.2 meter terjadi pada menit 70 samapai 150 yaitu berada di pulau Pagerrungan. Untuk run-up maksimum yang ketiga yaitu dengan ketinggian 0.7 sampai 0.3 meter yaitu berada di Pantai Lombang samapai ke Badur, karena temapt ini merupakan tempat yang jauh dari sumber sehingga run-up yang berada di tempat ini juga menjadi rendah. Untuk run-up minimum tsunami 0 meter tetap berada di Pulau Masalembu dan daerah di selatan Sumenep seperti Pantai Slopeng, Ambunten dan Pasongsongan serta Kalianget.

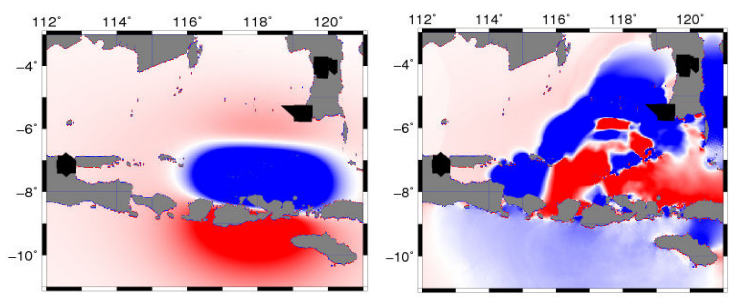

(a)

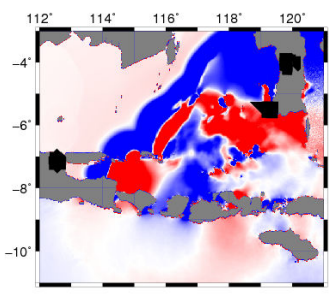

(c)

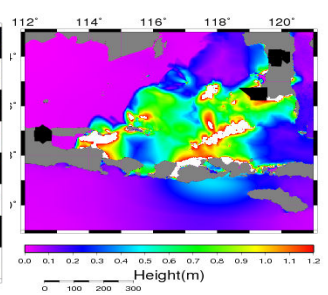

(d)

Gambar 14. (a) sebaran tsunami Pada menit ke-0 (b) menit ke-60 (c) menit ke-80 (d) Run-up maksimum.

\section{KESIMPULAN}

Dari pemodelan ini bisa diketahui bahwa daerah yang rawan terhadap tsunami yaitu pulau Sepanjang, Kangian, Pagerrungan, Raas, Spudi, Gili Raja, Gili Genting, Talango, Tanjug, Kalianget, Pragaan dan Tanjung Lopak. Sedangkan wilayah yang 
tidak rawan terhadap bencana tsunami adalah pulau Masalembu, Pantai Slopeng, Ambunten dan Pasongsongan

\section{DAFTAR PUSTAKA}

Bamelen, Van R.W., 1949. The Geology of Indonesia. Government Printing Office the Hague

Budiman., Diposaptono, Subandono, 2006. Tsunami. Penerbit Buku Ilmiah Populer. Bogor.

Dudley, Walter, C., Lee, Min., 1998. Tsunami. A Latitude 20 Book, University of Hawai'I Press. Honolulu.

Global CMT Catalog, 2010. Seismic Database. http://www.global cmt.org/cgibin/globalcmt-cgi

Imamura, F., Yalciner, A.C., Ozygurt., 2006. Tsunami Modeling. DCRC (Disaster Control Research Center). Tohuku University. Japan

Koshimura, Shunichi, 2007. TUNAMI-CODE (Tohuku University's Numerical Analysis Model for Investigation of Tsunami). Tohoku University

Kundu, Anjan, 2007. Tsunami and Nonlinear Waves. Springer. Berlin

Mokhtar, Zaty Akhtar, 2007. Study Appropriate Modeling of Tsunamis in Malaysia for Risk Efaluation. Malaysian Meteorological Department.

NOAA (National Oceanic and Atmospheric Administration), 2009, Tsunami Catalog. http://ngdc.noaa.gov/hazard/tsu_db.shtml

Nelson, Stephen, A., 2009. Tsunami (Natural Disaster). Tulane Univrsity. http://disaster.elvini.net/tsunami.cgi. tanggal akses 15 Agustus 2009.

PB, Triton, 2009. Sejarah Bumi dan Bencana Alam (Mengenal Sains). Tugu Publisher. Jogjakarta

Prasetya, Tiar, 2006. Gempabumi (Ciri dan Cara Menanggulanginya). Gita Nagari. Yogyakarta

Rudyanto, Ariska, 2008. A Prototype of Web-Aplication for Tsunami Database Along Southern Coast of Java Island. Tsukuba. Japan

Sengara, I Wayan,. dkk. Seismic Hazard Assessment in Denpasar - Bali. (disamapaikan dalam workshop The Regional Workshop on Best Practices in Disaster Mitigation)

Sitake, kenji, 2002. Tsunams. Aktive fault research center, GSJ/AIST, tsukuba, Japan 
USGS (United State Geological Suurvey), 2010. Seismic Database. http://www.usgs.gov

Wangsadinata, Wiratman,. Menyikapi Bahaya Tsunami. (makalah dipresentasikan pada Seminar Nasional Sehari "Antisipasi Gempa dan Tsunami dalam Rangka Penyelamatan Jiwa dan Harta” BMG, Jakarta, 31 Maret 2005 )

WinITDB, 2007. Integrated Tsunami Dtabase for the World Ocean. Tsunami Laboratory.ICMMG SD RAS. Novosibirsk. Russia 